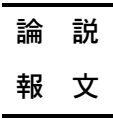

下水污泥からのリン回収プロセスの開発

\author{
萩 野 隆 生 ${ }^{1}$ 平 島

\section{Development of a Process for Recovering Phosphorus from Sewage Sludge} \\ Takao HAGINO ${ }^{1}$ and Tsuyoshi HIRAJIMA ${ }^{2}$ \\ ${ }^{1}$ EBARA Corporation, Environmental Technology Development Center, 4-2-1, Honfujisawa, Fujisawa, \\ Kanagawa 251-8502, Japan \\ ${ }^{2}$ Faculty of Engineering, Kyushu University, Fukuoka, Fukuoka 812-8581, Japan
}

岡川2

\begin{abstract}
A novel process for effectively recovering phosphorus from waste has been developed. By this process, magnesium ammonium phosphate (hereinafter referred to as MAP) is recovered from anaerobic digestive sludge in sewage. The MAP recovery process involves recovering inorganic fine particles, which include the MAP particles, from digestive sludge through a successive line of separating devices such as, a vibrating screen, a hydro-cyclone, and a revolving-cylindrical type thin flow separator or multi-gravity separator. Continuous tests for MAP recovery carried out to study the performance of this process indicate that it was possible to recover about $90 \%$ of MAP.
\end{abstract}

Key words: Sewage, Sludge, Phosphorus, Recycle, MAP, Cost

\section{1. 緒言}

資源のリサイクル問題は人口が多くなるほど，生活環 境が発展するほど切実さを増す問題である。今日，数多 くの資源に対するリサイクルプロセスが提案され実用化 されているものも少なくないが，歴史的に見て資源りサ イクルプロセスの実用化を実質的に阻んできた最大の障 壁は「リサイクルコスト」である場合が多い。

人間にとって必須元素でありかつ枯渴が懸念されてい る資源の一つとしてリンがあげられる。リンは，人間を 始めとする動物にとって体内の骨やアミノ酸等を構成す る必須元素であり，植物にとっても肥料三大元素の一つ として欠かすことのできない元素である。我が国はリン 鉱石を注ぼ 100\%輸入にたよっているが，欧米ではリン を戦略物資として位置付俥俞出規制を行っている国も見 られる。我が国はリン資源をリン鉱石だけでなく肥料, 農作物, 海産物等の形態で輸入しているが, リン資源輸 出国からの供給が十分でなくなる事態が生じれば，即座 にわが国の社会, 経済及び個人生活に甚大な影響を与え ることになる。輸入されるリンの多くは最終的に人間が

キーワード：下水, 污泥, リン, 回収, MAP, コスト

1 (株) 荏原製作所環境事業カンパニー環境システム事業 部水・環境開発室応用技術グループ

2 九州大学大学院工学研究院地球資源システム工学部門 資源処理工学研究室

平成 17 年 8 月 26 日受理
掑取するべき食物を生産するために使用される。人が食 したリンはその $2 / 3$ 以上がし尿として下水道放流され, 下水処理場にて活性污泥処理等の排水処理プロセスを経 た後に, その大部分が下水污泥中に濃縮される。下水污 泥に濃縮されなかったリンは下水放流されるが，そのリ ンは, 水域, 海域に打いて水環境污染物質として作用す るため, 下水放流水中リン負荷量が多くなると場合に よっては富栄養化等の環境悪化を招くことにもなりかね ない。リンが水環境に与える富栄養化負荷は COD の 140 倍以上, 窒素の 7 倍以上に及ぶと言われている1)。今後, 水環境保全の観点から, また水環境に打ける環境負荷排 出税や排出権取引等が導入されるよらな時代が到来した 時には, 下水から取り除かれ污泥に濃縮されるリンの量 は今以上に大きくなると思われる。

下水污泥は有料で処分される廃棄物でありその割合は 廃棄物中で最も大きい。この下水污泥からリンを全量回 収することができれば我が国の輸入リン資源の2３割を 賄えるといら試算がある。下水污泥からリンを回収する 技術は 20 年以上前から様々考案されて扣り, その方式や 回収形態も様々存在し技術的には完成された処理フロー と思えるプロセスも2，3 あるよらに思われる。しかしな がら, 実際はこれらのリン回収方式はどれひとつとして 今日に拈いて広く普及することはなかった。筆者らは, 污 泥からのリン回収技術が広く普及しない最大の障壁とし て「リン回収コスト」にあると考えた。ただ，個々の処 理コストに関する情報は企業秘密に属する問題も含むた 
下水污泥からのリン回収プロセスの開発

めに一般的には開示されない場合が多く，これまで整理 されることは少なかった。

このような背景から本研究では,「下水からのリン回収 技術として自立採算性のある安価なプロセスを開発す る」という最終目標を設定し, 具体的な研究開発に取り 組み始めた ${ }^{2,3)}$ 。

まずは, 従来法としての下水からのリン回収技術を「処 理コスト」といら視点で定性的に整理した。次に,「処理 コスト」といら観点から見た従来技術の問題点を打開す るための方法を模索し, 全く新しい概念の低コストリン 回収方式を考案した。さらに, 本処理方式をパイロット スケールの実験装置として構築し, 実験装置の運転結果 より得られた本システムのリン回収性能及びリン回収コ ストの評価を行った。

\section{2. 既存の下水からのリン回収技術}

下水由来のリンを回収する方法として，これまでに開 発されている既存方式のらち実用化レベルに達している 主なプロセスを Table 1 に示す。リン回収の対象物とし ての形態は, 下水放流水, 返流水, 余劋污泥, 消化污泥, 污泥焼却灰と様々であるが，対象成分は匡とんどがリン 酸であり, 回収物はヒドロキシアパタイト (HAP), もし くはリン酸マグネシウムアンモニウム（MAP）が多い。 本稿では前者を HAP 法, 後者を MAP 法とする。

$\mathrm{HAP}$ 法は液中の $\mathrm{PO}_{4}{ }^{3-}$ と $\mathrm{Ca}_{2}{ }^{+}$及び $\mathrm{OH}^{-}$が結合して生成 するヒドロキシアパタイト $\mathrm{Ca}_{10}(\mathrm{OH})_{2}\left(\mathrm{PO}_{4}\right)^{6}$ の生成反応 （（1）式）を利用して, 液中の $\mathrm{PO}_{4}{ }^{3-}$ を結晶化させる方式 である。本方式では，石灰等の薬剤を添加することによ り $\mathrm{Ca}_{2}{ }^{+}$や $\mathrm{OH}^{-}$を供給し液中を過飽和状態とする必要が ある。結晶化する HAP を付着させるためのベットとなる 脱リン接触材としてはリン鉱石, 骨炭, 珪酸カルシウム
水和物等を用いるのが一般的である。回収した HAP はリ ン酸質肥料や工業用リン酸の原料として用いる方法が検 討されている4)。

$$
10 \mathrm{Ca}_{2}{ }^{+}+2 \mathrm{OH}^{-}+6 \mathrm{PO}_{4}{ }^{3-} \rightarrow \mathrm{Ca}_{10}(\mathrm{OH})_{2}\left(\mathrm{PO}_{4}\right)_{6}
$$

MAP 法は液中の $\mathrm{PO}_{4}{ }^{3-}$ と $\mathrm{NH}^{4+}$ 及び $\mathrm{Mg}^{2+}$ の反応によっ て生成するリン酸マグネシウムアンモニウム $\mathrm{MgNH}_{4} \mathrm{PO}_{4}$ の生成反応（(2) 式）を利用して, 液中の $\mathrm{PO}_{4}{ }^{3-}$ を結晶 化させる方式である。本方式では, 塩化マグネシウムや 苛性ソーダ等の薬剤を添加することにより $\mathrm{Mg}^{2+} や \mathrm{OH}^{-}$ を供給し液中を過飽和状態とする必要がある。一般的に MAP 法は結晶生成速度が速いため, 脱リン接触材は使用 しない場合が多い。回收した MAP はリンとアンモニア を等モルずつ含有するのでリン酸アンモニウム系肥料等 の原料として用いる方法が検討されている5)。

$$
\mathrm{Mg}^{2+}+\mathrm{NH}_{4}{ }^{+}+\mathrm{PO}_{4}{ }^{3-} \rightarrow \mathrm{MgNH}_{4} \mathrm{PO}_{4}
$$

処理方式(1)～(4)（Table 1）の中で(1)～(4)の方式は全て 薬品を使用し, その薬品は脱炭酸処理用の希硫酸, Ca 添 加剂の消石灰, $\mathrm{Mg}$ 添加剂の水酸化マグネシウムや塩化 マグネシウム, $\mathrm{pH}$ 調整剤の苛性ソーダや硫酸等多岐にわ たり，それぞれプロセス毎に必要に応じて使用される。 各々の処理プロセスの基本構成を基に各方式を化学量論 的, 物質収支的に分析し, 実装置に打少留まり等も 考え合わせて判断すると, (1)～(4)の方式による薬品コス トは少なくとも約 40 円〜約 150 円/ $(\mathrm{kg}-$ 回収産物) は必 要になると思われる。さらに, 処理プラントを構成する ポンプ, 摚拌機, ブロア, 乾燥機, 固液分離装置等の装 置を稼働させる為の動力は少なくとも約 $20 \mathrm{kw}$ 以上は必 要になると考えられ, 電力単価を 12 円 / kwh とした場合, いずれの方式も少なくとも約 20 円 / $(\mathrm{kg}-$ 回収産物 $)$ 以上 の動力費用が必要となると思われる。

(1)～(4)の方式によりリンを回収するためには，以上に 推定した薬品コストや動力コストが必要となるがこれら

\begin{tabular}{|c|c|c|c|c|c|}
\hline $\mathrm{P}$ recovery system & Basic operations & Substance & Ingredient & $\begin{array}{l}\text { Recovered } \\
\text { products }\end{array}$ & Main expenses \\
\hline $\begin{array}{l}\text { (1) Contact } \\
\text { Crystallization }\end{array}$ & $\begin{array}{l}\text { Decarboxylation } \\
\text { Crystallization } \\
\text { (Contact media) }\end{array}$ & Sewage effluent & Phosphoric acid & HAP & Chemicals \\
\hline $\begin{array}{l}\text { (2) MAP crystallization } \\
\text { in returned water }\end{array}$ & $\begin{array}{l}\text { Anaerobic digestion } \\
\text { Crystallization } \\
\text { (Fluid bed) }\end{array}$ & Returned water & Phosphoric acid & MAP & Chemicals \\
\hline $\begin{array}{l}\text { (3) HAP crystallization } \\
\text { in returned water }\end{array}$ & $\begin{array}{l}\text { Anaerobic digestion } \\
\text { Crystallization } \\
\text { (Fluid bet) }\end{array}$ & Returned water & Phosphoric acid & HAP & Chemicals \\
\hline (4) Phostrip & $\begin{array}{l}\text { AO process } \\
\text { Sludge separation } \\
\text { Crystallization or } \\
\text { Coagulation settling }\end{array}$ & Activated sludge & Phosphoric acid & HAP & $\begin{array}{l}\text { Chemicals } \\
\text { Power consumption }\end{array}$ \\
\hline
\end{tabular}

Table 1 Technologies applied for the removal of phosphorus from sewage 
のコストには, プラントのイニシャルコスト, 運転維持管 理コスト，回収産物の運搬費用等は含んでおらず，それら を含めた総コストはさらに大きくなる。以上の考察より, 薬品費と動力費の合計だけでコスト計算した場合でも, (1) 〜 (4)のリン回収コストはほとんどの処理方式において少 なくとも約60円/ ( $\mathrm{kg}$-回収製品) 以上になると考学られる。

一方, 回収した MAP や HAP 等は有価物としてリサイ クルされるが，調査により実際に実用化されている(1), (2), (4)等での引取りの実勢価格は, MAP, HAP ともに約 $0 \sim 28$ 円 $/ \mathrm{kg}$ - 回収製品と值幅の広い引取り実績があるこ とがわかった。場合によっては無料または有償で引き 取ってもらら場合もあるという実態が明らかになった。

調査上, 回収リン産物としての MAP の最高引き取り 価格であった 28 円 $/ \mathrm{kg}$-回収 MAPをベースにコスト計算 をしてみる。MAP は常温下では 1 分子中にリンと窒素と マグネシウムを 1 分子ずつと6つの水分子を含有する(構 造式: $\left.\mathrm{MgNH}_{4} \mathrm{PO}_{4} ・ 6 \mathrm{H}_{2} \mathrm{O}\right)$ ので分子量は 245 である。この MAP を純度 $100 \%$ で $1 \mathrm{~kg}$ 回収するためには $1000 \div 245=$ $4.1 \mathrm{~mol}$ の $\mathrm{Mg}$ を必要とする。MAP 晶析反応に使用する $\mathrm{Mg}$ 源はスラリー状で反応性の悪い水酸化マグネシウム よりも溶解性で反応性の高い塩化マグネシウムを使用す る場合が多いが，塩化マグネシウムの関東・新潟エリア の取引価格は製品 35\%液体のローリーベースで 539 円/ $\mathrm{kg}-\mathrm{Mg}$ である。これより $\mathrm{Mg}$ の原子量 24 として $4.1 \mathrm{~mol}$ の $\mathrm{Mg}$ の費用は $4.1 \times 24 \times 539 \div 1000=53$ 円となる。つまり $1 \mathrm{~kg}$ の MAP を生産するのに Mg だけでも 53 円のコスト が必要となるにもかかわらず MAP は最大でも 28 円 / kgMAP でしか売却できないといらのが現実である。

これら回収した MAP や HAP の利用方法は, 一般的に はリン含有物質としてリン肥料, 化学製品原料, 土䁃改良 剂等として再利用される場合が多い。回収 MAP や回収 HAP 中の重金属類濃度は肥料取締法の規制值を十分に下 回っている場合が多く,さらにその肥料としての効能はこ れまでに論文発表等でも十分に証明されているにもかか わらず，「何が混入しているか分からない下水污泥由来の リン」といらイメージが先行していること, リン鉱石輸入 価格の低位安定していること等を理由にMAP引取りの実 勢価格は今日においても上昇する気配が見られない。

以上のことから, 既存方式のリン回収技術は, 処理に 必要な薬品コスト, 動力コスト等が大きいために, 最終 的には「リン回収コスト」》「リン資源市場調達コスト」 となるケースがほとんどであり, 回収リン含有物の売却 益でリン回収コスト全て賄ら「自立採算性のあるリン回 収技術」が現状の技術では困難であることが判明した。 このことが今日に打いても下水污泥からのリン回収プロ セスが全国的に広がりを見せない最大の理由の一つであ ると判断する。

\section{3. 污泥中に自然発生する MAP に関する調査}

\section{1 嫌気性消化污泥脱水ケーキの中の結晶物の存在}

我が国の下水処理場約 1200 施設の内 $1 / 4$ にあたる約 300 施設では，下水污泥の嫌気性消化処理を採用してい る。下水処理により発生した混合生污泥を嫌気性消化処 理することにより污泥の減量化及びメタンガス回収が行 えるが, 消化污泥中には固形物として消化残査, メタン 生成菌等の微生物, 無機物質等が, 溶解物質として $\mathrm{NH}_{4}{ }^{+}$, $\mathrm{PO}_{4}{ }^{3+}, \mathrm{CO}_{3}{ }^{2-}$ 等が多く含まれる。消化污泥は脱水処理さ れて固形物は脱水ケーキとなるがその脱水ケーキを良く 観察するとキラキラと光る $0.3 \sim 1.0 \mathrm{~mm}$ 程度の結晶物が ケーキ中に散りばめられているのを目視で簡単に発見す ることができる。この結晶物が MAP であることは古く から知られていることである。MAP は pH 7.0〜 7.6 の弱 アルカリ領域である消化槽内では徐々に生成するが $\mathrm{pH}$ $5.5 \sim 6.5$ の弱酸性領域である混合生污泥中では生成しな い。消化污泥中の MAP 構成成分濃度はそれぞれ $\mathrm{NH}_{4}-\mathrm{N}$ : 約 $1000 \sim 1500 \mathrm{mg} / \mathrm{l}, \mathrm{PO}_{4}-\mathrm{P}$ : 約 $250 \sim 500 \mathrm{mg} / \mathrm{l}, \mathrm{Mg}^{2+}$ : 約 20 $\mathrm{mg} / \mathrm{l}$ 以下であり $\mathrm{Mg}$ 律速により消化槽内の MAP 生成反 応が制限を受けていると考えられる。消化污泥中に自然 発生した MAP 粒子は固形物なので, 污泥の脱水処理工 程において脱水ヶーキ側に移行し, 最終的にはピロリン 酸マグネシウムの形態で焼却灰まで残留する。つまり污 泥中の MAP 性リンは回収されないまま最終的には埋立 処分されている。一方, 脱水ろ液中の高濃度の $\mathrm{NH}_{4}-\mathrm{N}$ や $\mathrm{PO}_{4}-\mathrm{P}$ は返流水として水処理系に戻り一般的には生物学 的脱窒・脱リン処理や化学的脱リン処理が施されるが, 先 に示した Table 1 の(2), (3)等の処理プロセスによりその 一部が回収されている場合もある。

ここで, 筆者らは, 污泥返流水中の溶解性リンを高価 な $\mathrm{Mg}$ 系添加剤の使用により MAP を生成し回収するの ではなく, 消化污泥中に自然発生して存在するが全く回 収されていないMAP粒子に着目し，このMAPをできる だけ低コストで回収するプロセスの開発を目指すといら 方針を立てた。そこでまずは次節に拈いて，消化污泥中 の MAP 粒子の実態調査を行った。具体的には実際に稼 働する下水処理場より採取した消化污泥を用いて，消化 污泥中の MAP 量の測定方法の検討, 及び複数の消化污 泥の性状分析による MAP またはりンの形態について調 查を行った。

\section{2 消化污泥中 MAP 量の測定方法検討}

\subsection{1 污泥の希釈によるMAP分離}

前節で述べたように污泥中の MAP の存在は污泥脱水 ケーキ中のキラキラと光る結晶物から確認できるが，そ の量を定量的に測定することは難しい。なぜなら，下水 污泥中には $\mathrm{Si}, \mathrm{Fe}, \mathrm{Al}, \mathrm{Ca}$ 等を含む様々な化合物微粒子 


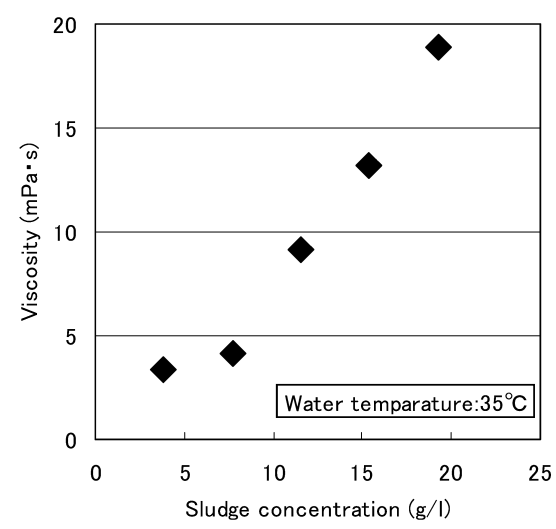

Fig. 1 Relationship between sludge concentration and viscosity.

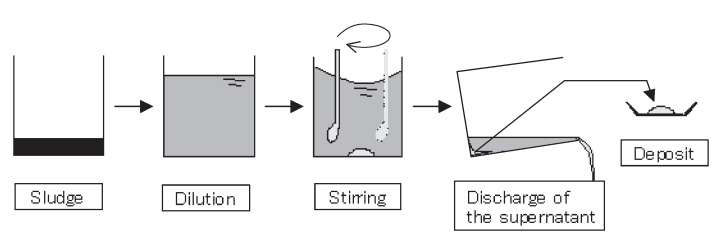

Fig. 2 Procedure for MAP Separation.

が存在する上，下水由来の植物の種子や木屑や髪の毛等 の夾雑物も混在しているからである。しかし，MAP は物 性としては密度が約 $1.7 \mathrm{~g} / \mathrm{cm}^{3}$ と比較的大きく, 脱水ヶー キを手でほぐしてピンセットて分離できる MAP 結晶は 約 $0.5 \mathrm{~mm}$ 約 $1.0 \mathrm{~mm}$ 程度の大きさのものもあることか ら, 他の微粒子と比較して沈降性が大きいのではないか と推定した。そこで，污泥を数倍に希釈して粘性を小さ くすることで污泥から沈降分離する実験を試みた。

Fig. 1 飞污泥濃度と粘性の関係, Fig. 2 飞MAP 分離操 作手順をそれぞれ示す。

消化タンク内は中温消化の場合通常 $35^{\circ} \mathrm{C} に$ 保たれて いる。Fig. 1 は A 処理場より採取した消化污泥を $35^{\circ} \mathrm{C}$ に 加温し, 同じく $35^{\circ} \mathrm{C}$ に加温した水道水で段階的に希勫 することで污泥濃度を減少させて粘性を測定したデータ をプロットした図である。污泥の希釈倍率が大きくなる ほど粘性が低下し，5 倍希釈する場合には粘性は 18.9 $\mathrm{mPa} ・ \mathrm{~s}$ から $3.4 \mathrm{mPa} ・ \mathrm{~s}$ まで低下した。

污泥から MAPを分離する方法に関して検討した結果, Fig. 2 に示寸ように消化污泥を約 5 倍に希釈して攪拌後 約 2 分静置し上澄又水を除去することで底部に沈降した MAPを主体とする無色透明の沈殿物粒子を得ることが できることが分かった。

\subsection{2 分離回収MAPの性状分析}

Table 2 飞MAP 沈殿物の定量分析結果, Fig. 3 飞 MAP の粒径分布をそれぞれ示す。消化污泥から希釈沈降分離
Table 2 Quantitative analysis of a MAP deposit

\begin{tabular}{lcc}
\hline Element & $\begin{array}{c}\text { Weight percent } \\
(\mathrm{wt} \%)\end{array}$ & Mole ratio \\
\hline $\mathrm{P}$ & 11.5 & 1.00 \\
$\mathrm{Mg}$ & 8.8 & 0.99 \\
$\mathrm{Si}$ & 1.1 & - \\
$\mathrm{Fe}$ & 0.9 & - \\
$\mathrm{Al}$ & 0.5 & - \\
$\mathrm{Ca}$ & 0.4 & - \\
Other metals & 0.6 & - \\
$\mathrm{N}$ & 5.0 & 0.97 \\
\hline
\end{tabular}

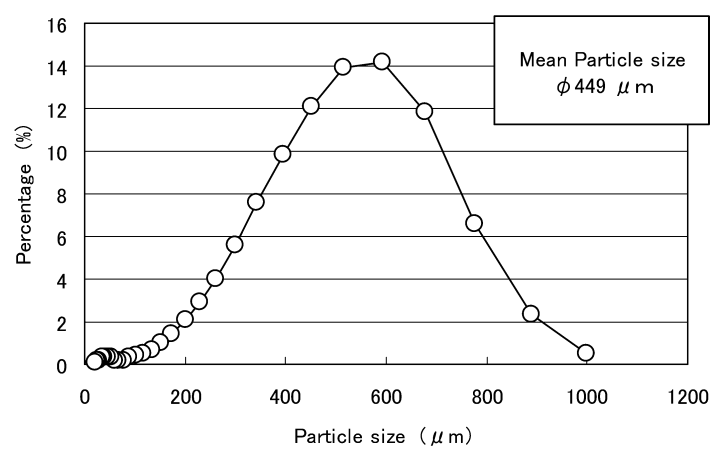

Fig. 3 Particle size distribution of MAP.

法で回収した無色透明の沈殿物をデシケータ中で24時間 以上常温乾燥した後の試料に対して蛍光 X 線分析装置 （XRF；株）リガク社製，RIX3000）による定量分析を 行った結果, Table 2 に示すように $\mathrm{P}$ と Mg が注涪等モル 存在することが分かった。さらに，本試料に対して下水 道試験法に従ったケルダール窒素を測定すると, P と Mg とほぼ等モルの Nが存在することが分かった。これらの 結果より, Fig. 20万方法で沈殿分離して得た沈殿物がMAP であると推定された。

次に，この沈殿物常温乾燥物をレーザー回折／散乱式 粒度分布測定装置（（株）堀場製作所製，LA-910）によ り粒径分布を測定したところ, Fig.3 に示すような 100 $\mu \mathrm{m} \sim 1000 \mu \mathrm{m}$ の存在率が $95 \%$ 以上で平均粒径 $449 \mu \mathrm{m}$ とい ら粒径分布が得られた。

\subsection{3「粗MAP」という污泥中MAP量の指標値}

Fig. 4 飞添加 MAP と回収 MAP の関係を示す。なお, Fig. 4 中の横軸の「MAP 添加量」は元々の污泥中に存在 した既知のMAP量を含めた合計值であり，その值はFig. 4 の白拔き○印で示した。Fig. 2 の分離操作を経て分離回 収しかつ Fig. 3 亿示した粒径分布が既知であるこの MAP 粒子を元々の消化污泥に添加量を変光て添加し，十分に 攪拌した後に Fig. 2 亿示す方法で再びMAPを分離回収し たところ，添加した MAP の 96〜97\%が回収できること が分かった。このことは, Fig. 2 の方法により活泥を 5 倍 


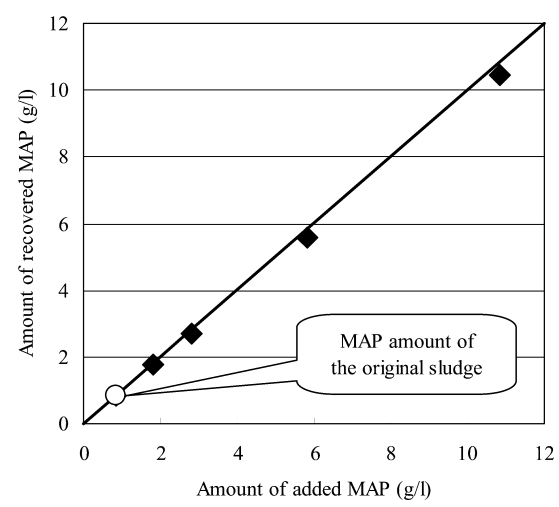

Fig. 4 Relationship between the recovered amount of MAP and the amount of added MAP.

希釈して沈降分離することで污泥中に存在する $100 \mu \mathrm{m}$ 以 上の MAP 粒子が 95\%以上回収することができることを 意味すると考光た。以上の結果を踏まえて，この Fig. 2 の方法で得られる沈殿物を「粗 MAP」とし，その量を污 泥中に存在する MAP 量の指標値として以後用いること とした。また, 別の回分実験を行った結果, 常温時に 6

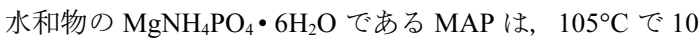
時間乾燥時には水和水分子と一部のアンモニアが揮発し 重量が 45\%減少することが判明したことから, 粗 MAP 量はFig. 2 の方法により分離した沈殿物を $105^{\circ} \mathrm{C} て ゙ 10$ 時 間乾燥した後の重量を 0.55 で除して求めた。

今回, 開発したこの「粗 MAP」の評価方法により, 少 量の水とビーカー等があれば短時間で MAP の分離性能 を確認することができるため, 污泥中の MAP 概算量に 関する迅速測定法を新たに考案することができたとい兄 る。実際に 4 章で行った MAP 回収システム開発では, 本 方式の採用によりシステム評価速度がきわめて迅速に行 らことが可能になった。

\section{3 消化污泥中 MAP 量の実態調查}

\subsection{1 消化污泥中に存在する粗MAP量}

Fig. 5 に全国飞点在する 10 所の下水污泥嫌気性消化 施設から採取したから污泥中の粗 MAP 量を示す。この 10 r所は, 水処理系, 污泥処理系ともに鉄系助剤を使用 しない処理場として選んでいる。消化污泥中の MAP 量 は基質の濃度によって異なるので処理場によってばらつ きがあり粗 MAP 量としては $0.5 \sim 1.4 \mathrm{~g} / 1$ の範囲で存在し, その平均值は $0.8 \mathrm{~g} / 1$ であった。また, 一般的な消化污泥 中の全りン量を $850 \mathrm{mg} / \mathrm{l}$ とすると, 污泥に含まれる全り ン中の粗 MAP の割合は7〜20\%に達すると推定される。

\subsection{2 消化污泥の形態別リン比率}

Fig. 6 亿 M 処理場から採取した消化污泥の形態別リン 比率を示す。Fig. 6 より污泥中リン全体の約半分にあた

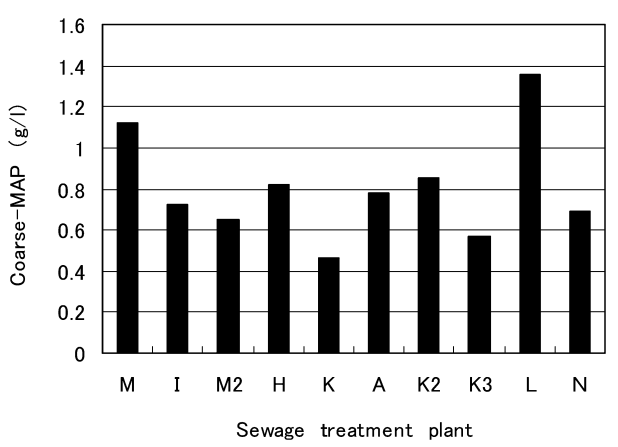

Fig. 5 Rate of recovered coarse-MAP from sewage sludge in 10 treatment plants.

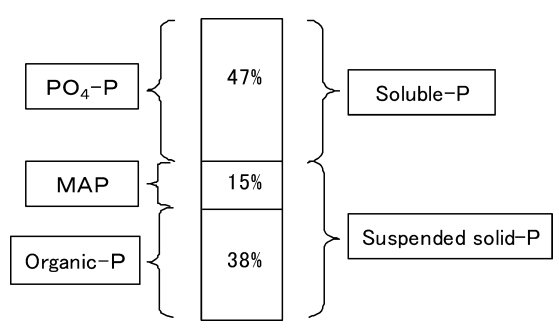

Fig. 6 Type of phosphorus in anaerobic digested sludge from $M$ treatment plant.

る47\%は溶解性のリンであり,残り 53\%は固形性リンで あるがその内訳は MAP が $15 \%$ でそれ以外の有機固形性 リンと思われる分が $38 \%$ あ゙あた。近年, 污泥の発生量 を軽減しかつバイオガスの回収率を高めるために污泥の 可溶化処理に関する研究が盛んに行われており, この分 野の研究が進展するに伴って $38 \%$ の有機固形性リンが減 少し溶解性リンと MAP リンの比率がますます高まると 予想される。

\subsection{3 污泥性状分析}

性状分析に供した污泥は, 下水污泥の嫌気性消化処理 として一般的な処理を行う A 処理場と, 消化污泥にポリ 硫酸第二鉄を添加している B 処理場の 2 箇所の処理場よ り採取した消化污泥である。B 処理場に扎いて消化污泥に ポリ硫酸第二鉄を添加するのは污泥中の $\mathrm{PO}_{4}-\mathrm{P}$ (約 250〜 $500 \mathrm{mg} / \mathrm{l}$ ）をリン酸鉄として固定し返流水中のリン 含有量を軽減するためである。Table 3 に污泥性状分析結 果, Photo. 1 粗MAPとして回収した沈殿物の写真を示す。 な打 Table 3 の $\mathrm{pH}$, TS (Total Solid: 蒸発残留物), SS (Suspended Solid: 懸濁物質), VTS (Volatile Total Solid: 強 熱減量一蒸発残留物), VSS (Volatile Suspended Solid: 強 熱減量一懸濁物質), 及び $\mathrm{PO}_{4}-\mathrm{P}$ の分析方法は全て JIS K1020 に準じ，M アルカリ度は下水道試験法に準じて 行った。

$\mathrm{A}$ 処理場の污泥は $\mathrm{PO}_{4}-\mathrm{P}$ が $360 \mathrm{mg} / \mathrm{l}$, 粗 MAP 量が 0.78 
下水污泥からのリン回収プロセスの開発

Table 3 Properties of digestive sludge

\begin{tabular}{ccccccccc}
\hline $\begin{array}{c}\text { Treatment } \\
\text { plant }\end{array}$ & $\begin{array}{c}\mathrm{pH} \\
(-)\end{array}$ & $\begin{array}{c}\text { TS } \\
(\mathrm{g} / \mathrm{l})\end{array}$ & $\begin{array}{c}\text { SS } \\
(\mathrm{g} / \mathrm{l})\end{array}$ & $\begin{array}{c}\text { VTS } \\
(\%)\end{array}$ & $\begin{array}{c}\text { VSS } \\
(\%)\end{array}$ & $\begin{array}{c}\text { PO4-P } \\
(\mathrm{mg} / \mathrm{l})\end{array}$ & $\begin{array}{c}\text { Alkalinity } \\
(\mathrm{mg} / \mathrm{l})\end{array}$ & $\begin{array}{c}\text { Coarse-MAP } \\
(\mathrm{g} / \mathrm{l})\end{array}$ \\
\hline $\mathrm{A}$ & 7.0 & 22.2 & 20.7 & 64.9 & 67.1 & 360 & 3890 & 0.78 \\
$\mathrm{~B}$ & 7.3 & 19.7 & 20.5 & 52.6 & 54.3 & 61.7 & 3210 & $<0.1$ \\
\hline
\end{tabular}

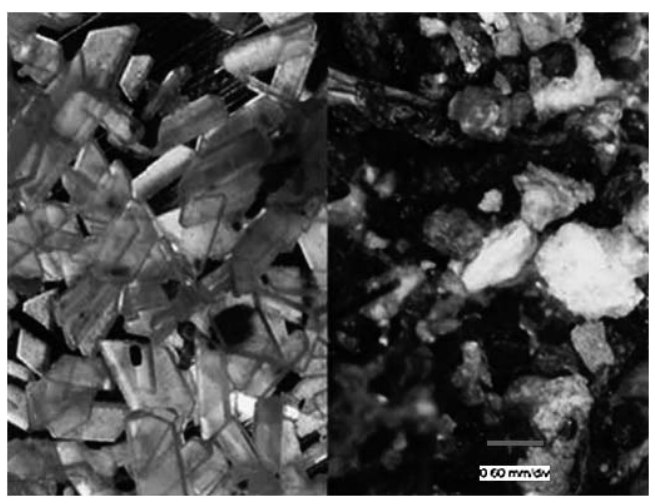

Photo. 1 Coarse MAP particles from sludge treatment plants A (left) and B (right).

g/1 それぞれ存在した。Photo. 1 からも粗 MAPとして回収 した沈殿物の多くが MAP の結晶であることが確認でき る。一方, B 処理場の污泥は $\mathrm{PO}_{4}-\mathrm{P}$ が $61.7 \mathrm{mg} / \mathrm{l}$, 粗 MAP 量が $0.1 \mathrm{~g} / 1$ 末満であった。Photo. 1 からも B 処理場の励 泥には MAP がほとんど存在しないことがわかる。B 処 理場污泥はポリ硫酸第二鉄が污泥に添加されていること から $\mathrm{PO}_{4}-\mathrm{P}$ の大部分がリン酸鉄として固定化されている と思われる。しかし, 污泥中に存在するリン酸鉄は回収 されずに廃棄物として焼却灰まで残留することになる。

\section{4. 消化污泥 MAP 回収システム実験}

\section{1 実験概要}

前章では消化污泥中に約 $0.8 \mathrm{~g} / 1$ の MAP が存在し, そ の MAP は密度約 $1.7 \mathrm{~g} / \mathrm{cm}^{3}$, 粒径約 $450 \mu \mathrm{m}$ で污泥中の他 の微粒子より沈降分離性が高いことを示した。そこで本 実験では，消化污泥中に自然発生して存在する MAPを 物理選別回収するシステムを考案し，そのシステムの回 収性能をパイロットスケールの実験装置により評価し た。筆者らが想定した処理フローは消費電力の比較的小 さい污泥移送ポンプや低速回転装置のみで構成し，から 洗浄水量は処理污泥量の $1 / 10$ 以下とする物理選別プロセ スを目指した。最終的には回収リン重量あたりのランニ ングコストが既存のリン回収プロセスの中で最小コスト であるプロセスの開発を目指した。

実験は予備実験とパイロット実験の 2 種類を行った。 予備実験では2インチ液体サイクロンによる活泥中MAP
分離実験を行った。パイロット実験では，予備実験結果 を鑑みて下水消化污泥とMAP粒子の特性を考慮した「消 化污泥 MAP 回収システム」と称するプラントを考案し, 処理規模約 $5 \mathrm{~m}^{3} / \mathrm{h}$ のパイロット実験装置により実証実験 を行った。予備実験は平成 14 年 8 月 20 日に行い, パイ ロット実験は平成 14 年 11 月 11 日〜22 日の期間に A下 水処理センターに打いて行った。

\section{2 予備実験（2 インチ液体サイクロンによる污泥中 MAP 分離実験)}

Fig. 7 に液体サイクロンによるMAP 分離実験結果を示 す。供試污泥は A 下水処理場の嫌気性消化污泥とし, 2 インチの液体サイクロンによるMAP分離実験を行った。 実験は液体サイクロンの運転条件として供給流速 $3.7 \mathrm{~m}^{3}$ / h, Spigot Cap(SC) 径 $3.2 \mathrm{~mm}$, Vortex Finder Cap (VC) 径 14 $\mathrm{mm}$ として行った。評価項目はMAP 回収率のみとした。 MAP 回収率 (\%) は（サイクロン濃縮污泥中 MAP / サ イクロン投入污泥中の MAP) $\times 100$ とした。液体サイクロ ンにより 97.1\%の MAP 回収率が得られた。MAPをアン ダーフロー産物として濃縮可能であったことから,さら に微粒子用比重選別機の適用により MAP の回収が可能 であるとの発想に至った。

\section{3 パイロット実験}

\subsection{1 污泥性状}

Table 4 に本実験で使用した消化污泥の性状を示す。実 験に供した污泥の性状は，pH，TS，VTS，PO4-P 等いず れも一般的な消化污泥の性状と判断できる值であり, 消 化污泥として問題は無かった。粗 MAP 量は $0.79 \mathrm{~g} / 1$ で あった。

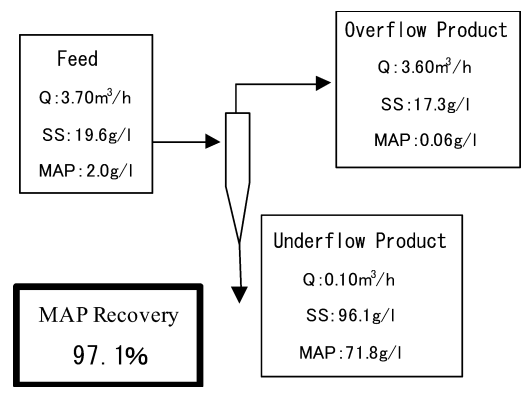

Fig. 7 Layout and results of the test for the separation of MAP using a hydrocyclone. 
Table 4 Properties of digestive sludge in the treatment plant A

\begin{tabular}{|c|c|c|c|c|c|c|c|}
\hline $\begin{array}{l}\mathrm{pH} \\
(-)\end{array}$ & $\begin{array}{l}\mathrm{TS} \\
(\mathrm{g} / \mathrm{l})\end{array}$ & $\begin{array}{l}\mathrm{SS} \\
(\mathrm{g} / \mathrm{l})\end{array}$ & $\begin{array}{l}\text { VTS } \\
(\%)\end{array}$ & $\begin{array}{l}\text { VSS } \\
(\%)\end{array}$ & $\begin{array}{l}\text { PO4-P } \\
(\mathrm{mg} / \mathrm{l})\end{array}$ & $\begin{array}{c}\text { Alkalinity } \\
(\mathrm{mg} / \mathrm{l})\end{array}$ & $\begin{array}{c}\text { Coarse-MAP } \\
(\mathrm{g} / \mathrm{l})\end{array}$ \\
\hline 7.2 & 20.4 & 18.0 & 64.4 & 68.3 & 347 & 4260 & 0.79 \\
\hline
\end{tabular}

Table 5 Equipment specifications

\begin{tabular}{cll}
\hline No & \multicolumn{1}{c}{ Equipment } & \multicolumn{1}{c}{ Specifications } \\
\hline (1) & Vibrating screen & Q: $5 \mathrm{~m}^{3} / \mathrm{h}, \phi 600 \mathrm{~mm}$, openings: $1.18 \mathrm{~mm}$ \\
(2) & 4inch hydrocyclone & Q: $20 \mathrm{~m}^{3} / \mathrm{h}, \phi \mathrm{VF}: 35 \mathrm{~mm}, \phi S C: 10 \mathrm{~mm}$ \\
(3) & 2inch hydrocyclone & Q: $4 \mathrm{~m}^{3} / \mathrm{h}, \phi \mathrm{VF}: 14 \mathrm{~mm}, \phi S C: 3.2,4.5,6.4 \mathrm{~mm}$ \\
(4) & MGS & Q: $0.06 \sim 0.18 \mathrm{~m}^{3} / \mathrm{h}$, Rotating speed: $280,300,318 \mathrm{rpm}$ \\
\hline
\end{tabular}

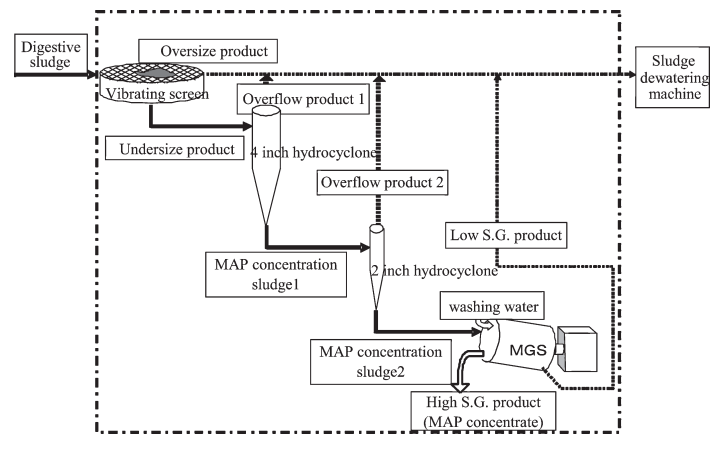

Fig. 8 Flow sheet for the recovery of phosphorus from sewage sludge.

\subsection{2 実験方法}

予備実験の結果より消化污泥中の MAP を分離回収す る手段として比重選別機等の適応が可能であることが示 唆されたことから，筆者らは「消化污泥 MAP 回収シス テム」と呼ぶ嫌気性消化污泥から直接 MAP 粒子を回収 するシステムを考案し，その処理性能を調査した。Fig. 8 に実験装置処理フロー, Table 5 に単位装置の機器仕様を それぞれ示す。実験ではそれぞれの単位装置を単独で運 転することで装置の最適運転条件を検討し，それぞれの 装置における最適運転条件時において処理性能を重初合 わせた時にシステム全体としてMAP回収率が $90 \%$ 以上, MAP 純度が $90 \%$ 以上を満足することを目標值とした。本 処理フローの構成は, 最初夾雑物除去装置として振動ふ るいを採用し MAP 以外の粒径 $1.0 \mathrm{~mm}$ 以上の夾雑物を取 り除き, 次に 4 インチ液体サイクロンで 1 段目の濃縮を 行い, その濃縮污泥を2 インチ液体サイクロンにて再度 濃縮する。2 段の液体サイクロンで濃縮した污泥は遠心 式薄流選別装置である MGS（Multi Gravity Separator）に より比重差による粒子の分離と洗浄を行う。4 インチ液 体サイクロン, 2 インチ液体サイクロンの VC 径と SC 径 は, Table 5 に示したものを使用した。

実験に使用した MGS の概略図を Fig. 9 に示す。MGS

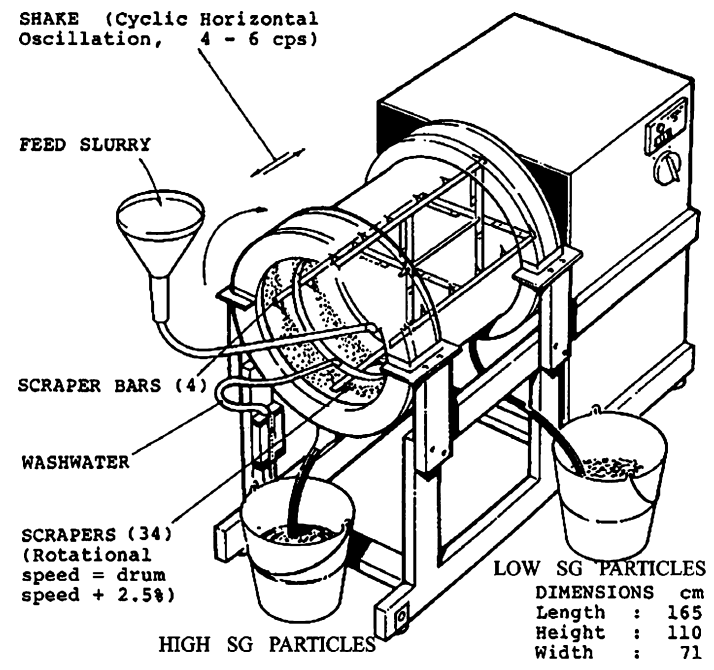

Fig. 9 Laboratory/pilot scale Mozley multi-gravity separator (MGS).

は, 汎用の摇動テーブルの水平面を丸めて回転ドラムに 押し込んだとでも表現できるもので，テーブル表面をド ラムに置き換えることによって通常の数倍の重力を粒子 に作用させることができる。このことにより，MGS では 汎用のテーブルよりも細かい粒子までの比重選別が可能 である。実験は, 所定洗浄水量及び所定ドラム回転速度 に調節した後, 実験スラリーを所定供給速度で供給して 行った。な抏，実験では特に記述していない場合はドラ ムの傾斜角度は 4 度, ドラムの振幅は $15 \mathrm{~mm}$, 振動数は 4.8 回/秒に固定して行った。

本実験の評価項目は主にMAP 回収率とMAP純度とし た。MAP 回収率は単位装置またはシステム全体に投入さ れる污泥中の MAP 量と得られた MAP 濃縮液中の MAP 量の比率から算出した。MAP 純度は粗 MAP 量に粗 MAP 中の MAP の含有率 $\left(105^{\circ} \mathrm{C}, 10\right.$ 時間乾燥物の塩酸溶解液 $\mathrm{PO}_{4}-\mathrm{P}$ 濃度より推定した 6 水塩 MAP 換算量の比率) とし て算出した。 


\subsection{3 実験結果}

\subsubsection{1 夾雑物除去装置}

Table 6 に夾雑物除去装置としての振動ふるいの分離実 験結果を示す。振動ふるいは, MAP 分離回収に先立って, 液体サイクロン等のMAP分離装置の分離性を阻害する比 較的大きな粒子（植物の種, 髪の毛等）をあらかじめ取 り除くことを主眼としている。後段の液体サイクロンの $\mathrm{SC}$ 径は，4 インチが $10 \mathrm{~mm}, 2$ インチが $3.2 \sim 6.4 \mathrm{~mm}$ であ り，それぞれの液体サイクロンの仕様としてはフィード 粒径をそれぞれ 2.0 $1.0 \mathrm{~mm}$ 以下にすることが望ましいと されている。そのため, 本実験では直径 $600 \mathrm{~mm}$, 目開き $1.18 \mathrm{~mm}$ の振動ふるいを使用し, 処理速度 $5.0 \mathrm{~m}^{3} / \mathrm{h}$ で污泥 を投入した。分離性能としては, 污泥当たりの夾雑物除 去量は $0.08 \%(\mathrm{v} / \mathrm{v})$, 夾雑物含水率は $87.4 \%, \mathrm{SS}$ 除去率は 0.5\%であった。MAP 回収率（振動ふるいにより污泥から 取り除かれずに污泥にとどまった MAP 粒子の割合）は 99.3\%であった。MAP 回収率が 99.3\%と高かったことか ら振動ふるいによるMAP排除量は無視できるレベルであ ると言える。ただし, 経験的には $1 \mathrm{~mm}$ 以上の粒径を持つ MAP 粒子を多く含む消化污泥も存在するので, 污泥が変 われば消化活泥中のMAPの粒径分布に応じてふるいの目 開きを最適化する必要があると思われる。

\subsubsection{MAP 濃縮装置}

Fig. 10 に MAP 濃縮装置としての液体サイクロン供給 原污泥中の粗 MAP 量とその量に対するアンダーフロー 産物中の粗 MAP 量の百分率（粗 MAP 回収率）との関係

Table 6 Result of the test with a vibration screen as a separation tool

\begin{tabular}{cccc}
\hline \multicolumn{2}{c}{ Foreign substances } & Suspended solids & MAP \\
\hline $\begin{array}{l}\text { Removal rate } \\
(\% \text { of sludge })\end{array}$ & $\begin{array}{c}\text { Moisture } \\
\text { content }(\%)\end{array}$ & $\begin{array}{c}\text { Removal rate } \\
(\%)\end{array}$ & $\begin{array}{c}\text { Recovery } \\
(\%)\end{array}$ \\
\hline 0.08 & 87.4 & 0.5 & 99.3 \\
\hline
\end{tabular}

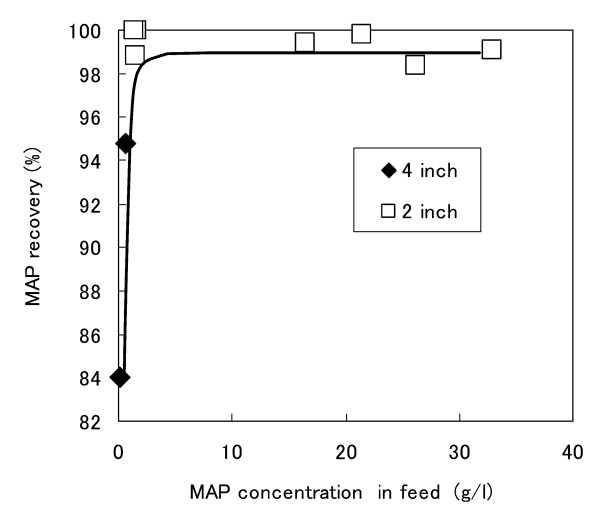

Fig. 10 MAP recovery as a function of MAP concentration in the feed during, hydrocyclone processing.
を示す。な拉，Fig. 10 には Table 5 の条件で行った結果 をすべてプロットしている。

4 インチ液体サイクロンへの活泥投入量は約 $20 \mathrm{~m}^{3} / \mathrm{h}$ で ある。原污泥粗 MAP 量が $0.08 \mathrm{~g} / 1$ と比較的小さい場合に は粗 MAP 回収率は $84.0 \%$ と低かったが, 原污泥粗 MAP 量が $0.57 \mathrm{~g} / 1$ と通常の濃度では回収率は $94.8 \%$ であり,ア ンダーフロー流量はフィードの約 $1 / 50$ であることから約 50 倍の濃縮が可能であった。

2 インチ液体サイクロンの污泥投入量は約 $4 \mathrm{~m}^{3} / \mathrm{h}$ であ る。4 インチ液体サイクロンで濃縮した MAP 濃縮液を原 污泥とするので原污泥粗 MAP 量は $1.34 \sim 32.9 \mathrm{~g} / 1$ と比較 的濃厚である。 $\mathrm{SC}$ 径を $6.4 \sim 3.2 \mathrm{~mm}$ にすることで濃縮倍 率を 8.2 ～40.3 倍まで変化可能であった。また，粗 MAP 回収率は, いずれも $98 \%$ 以上であり安定した濃縮処理が 可能であることが分かった。粗 MAP 量が約 $0.5 \mathrm{~g} / 1$ 以上 存在する消化污泥ならば 4 または 2 インチの液体サイク ロンにより約 95\%以上の回収率で MAP 粒子を濃縮する ことが可能であることが明らかになった。

\subsubsection{MAP 洗浄分級装置}

MGS は, 軸方向の反復運動と高速回転運動を同時に行 ら円筒体の内部にスラリーと洗浄水を供給し，スラリー から高比重粒子と低比重粒子を分離回収する装置であ る。円筒体は傾きをもち, 高比重粒子は差速回転するス クレーパーによって円筒内壁面上を上流側に掻き上げら れ, 洗浄水はカウンターフローで上流側から流される。 スズ，金，硫化鉱物などの高比重産物回収，微粒石炭の 脱灰, 脱硫などの応用例がメーカー及び筆者らの) が報告 しているが, いずれも密度 $2.5 \mathrm{~g} / \mathrm{cm}^{3}$ 以上を高比重産物と して回収したものであり, 密度約 $1.7 \mathrm{~g} / \mathrm{cm}^{3}$ と小さな密度 の MAP 粒子を有機污泥から高比重産物側に回収した例 は報告されていない。操作項目は投入污泥濃度, 投入污 泥量, 洗浄水量, 傾き, 回転速度等とし, MAP 回収に最 も適した運転条件について検討を行った。

ドラム回転速度 $318 \mathrm{rpm}$ として種々の実験条件を変化 させた場合の洗浄倍率と高比重側産物中の上澄水 SS の 関係を Fig. 11 に, 洗浄倍率と MAP 回収率との関係を Fig. 12 に示す。Fig. 11 より, 本実験条件では洗浄倍率 (洗浄水量 / 原污泥投入量) が大きくなるほど高比重側産 物中の上澄水は清澄であること, 洗浄倍率が 1.5 倍以上 で上澄水 SS は $10 \mathrm{~g} / 1$ 末満となることが分かった。しか し, Fig. 12 より, 洗浄倍率が大きくなるほど MAP 回収 率は低下するため, MAP 回収率 90\%以上を達成するた めには洗浄倍率を約 3 倍以下にする必要があることから， 洗浄倍率は $1.5 \sim 3$ 倍程度が適切と考えられる。

Fig. 13 に洗浄倍率 3.0 倍とした場合のドラム回転速度 と MAP 回収率との関係を示す。なお，同図中にドラム回 転速度 $280 \mathrm{rpm}$ で洗浄倍率 $1.5,2.0$ 倍の結果も示してい 
萩 野 隆 生・平島剛

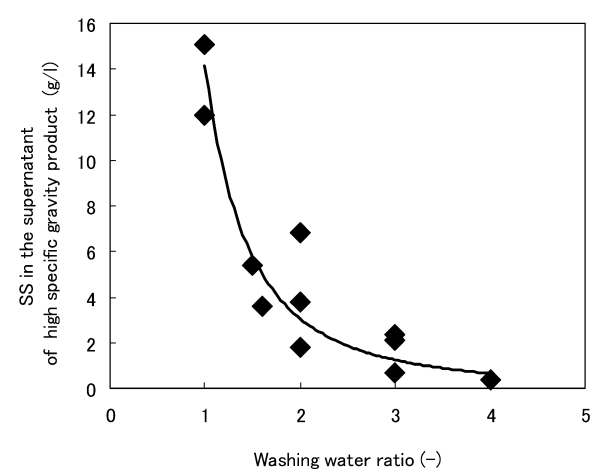

Fig. 11 Variation of SS in the supernatant of high specific gravity product from MGS as a function of washing water ratio. (MGS rotating speed: $318 \mathrm{rpm}$ )

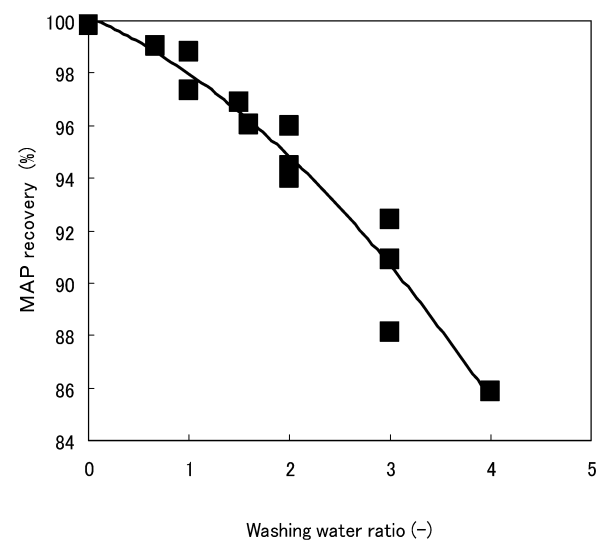

Fig. 12 Effect of washing water ratio on the recovery of MAP by MGS.

(MGS rotating speed: $318 \mathrm{rpm}$ )

る。ドラム回転速度が同一である場合は洗浄倍率が小さ いほど MAP 回収率は高く, 同一の洗浄倍率（3 倍）の場 合はドラム回転速度の増大に伴い MAP 回収率は大きく なった。上述したよらに MAP 密度は, 約 $1.7 \mathrm{~g} / \mathrm{cm}^{3}$ と小 さいため高比重側産物として回収するためにはMAP粒子 に大きな遠心力を与える必要があることが分かった。

Fig. 14 にドラム回転速度を $318 \mathrm{rpm}$ とし, 洗浄倍率 2 または洗浄水を加えなかった場合の MAP 負荷量と MAP 回収率との関係を示す。いずれの場合も MAP 負荷量 (1 分当たりに MGS に投入される MAP 量）が大きいほど MAP 回収率は高くなった。MAP 負荷量が $200 \mathrm{~g} / \mathrm{min}$ 以上 の場合に拈いて MAP 回収率は 95\%以上となった。

Fig. 15 にドラム回転速度を $318 \mathrm{rpm}$ とした場合の MAP 負荷量と MAP 純度との関係を示す。MAP 負荷量が大き いほどMAP純度は高くなり最大で $88.2 \%$ に達した。MAP 負荷量が $200 \mathrm{~g} / \mathrm{min}$ 以上の場合に括いて MAP 純度は $80 \%$ 以上となった。

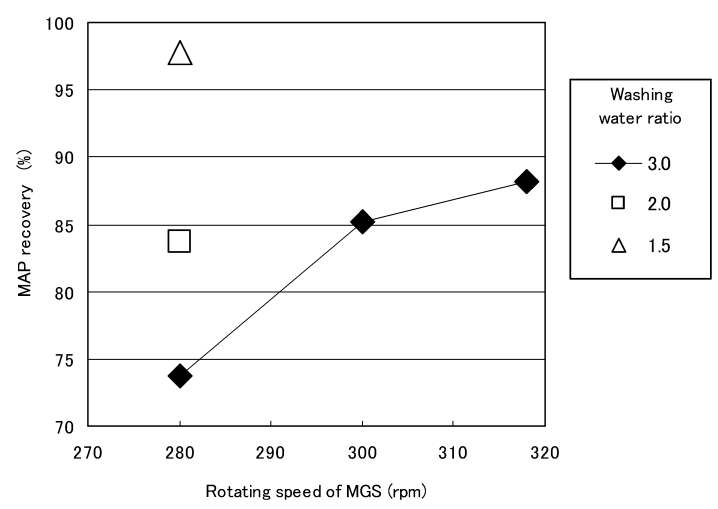

Fig. 13 Variation of MAP recovery as a function of MGS rotating speed.

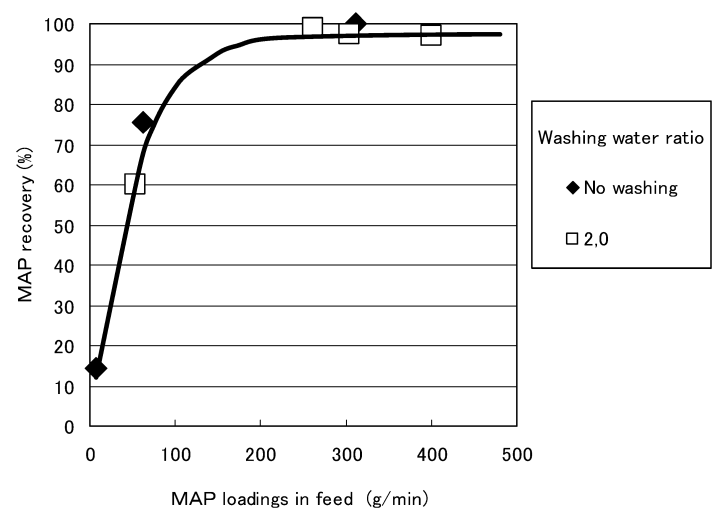

Fig. 14 Variation in the MAP recovery as a function of the MAP loading rate.

(MGS rotating speed: $318 \mathrm{rpm}$ )

Photo. 2 にMGS により分離したサンプルの $105^{\circ} \mathrm{C}$ 乾燥 物を示す。投入污泥 MAP 中の黒い粒子（写真：上）が MGS により分離され, 高比重側産物（写真: 左下）はよ り MAP 純度の高い白い粒子になっているのが分かる。

ドラム回転速度の増大, 洗浄倍率 (洗浄水) の低下, MAP 負荷量の増大に伴い高比重産物側の MAP 回収率は 増大した。このような挙動は, ドラム内部に保持される 粒子量に依存することが推察される。すなわち, ドラム 回転速度の増大, 洗浄水の低下, MAP 負荷量の増大に伴 いドラム内部に保持される MAP 粒子量が増大し, 形成 される粒子層も厚くなる。この結果, スクレーパーで高 比重産物側に掃き集められる MAP 量が増加し, 回収率 が増加したと考えられる。

以上の結果から, MGS による最適 MAP 分離方法を整 理すると, 前段の液体サイクロンによる MAP 濃縮はで きるだけ高濃度にすることが望ましく, その高濃度 MAP 污泥の MGS 供給量は MAP 負荷量ベースで $200 \mathrm{~g} / \mathrm{min}$ 以 上となるよう設定することが望ましい。洗浄倍率は産物 


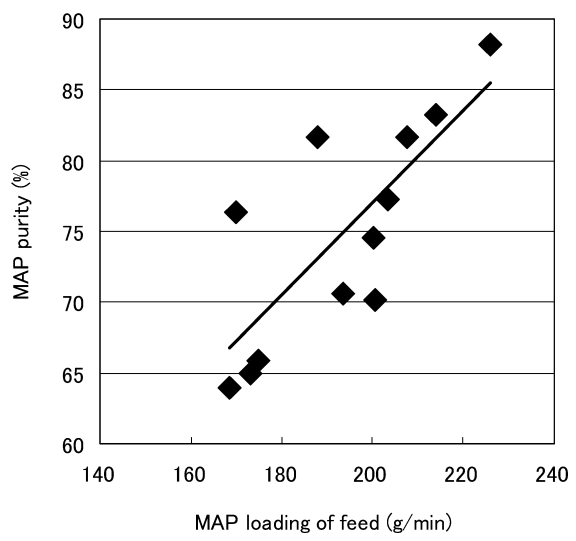

Fig. 15 Effect of loading rate of MAP in feed on the product purity.

(MGS rotating speed: $318 \mathrm{rpm}$ )

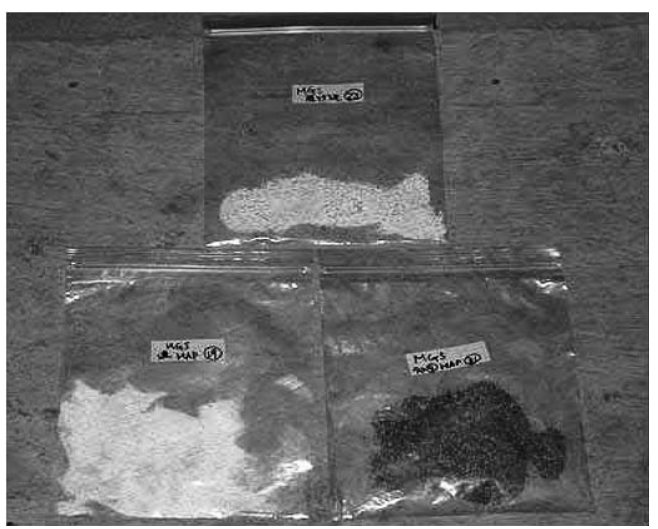

Photo. 2 Samples of materials from a MGS test dried at $105^{\circ} \mathrm{C}$.

(Upper: feed, Left: High specific gravity product, Right: Low specific gravity product)

の品位を高める上では 1.5 倍〜3.0 倍程度が望ましく, MAP 負荷量にもよるが全体の水量負荷はなるべく $5 \mathrm{~L} /$ min 以下が望ましい。傾きは $2 \sim 4$ 度の範囲が適正であ り, 回転数は $318 \mathrm{rpm}$ かできればそれ以上に設定するこ

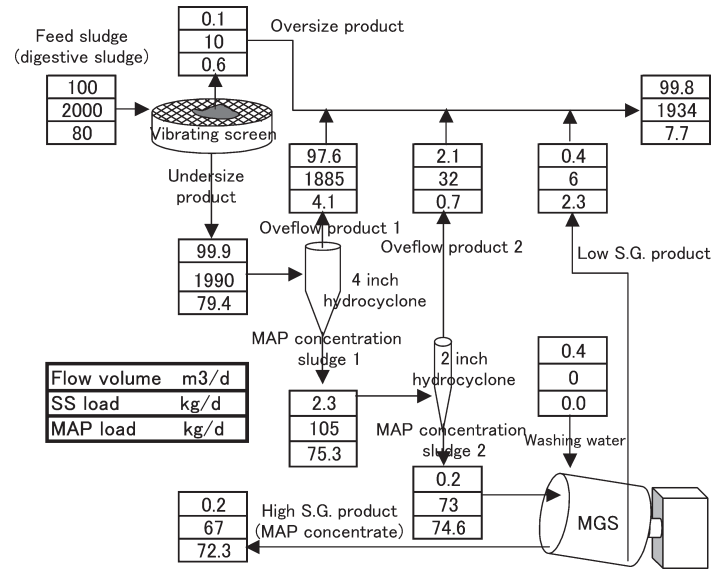

Fig. 16 Mass balance simulation for a MAP recovery system.

\section{とが望ましいと考えられる。}

\subsubsection{4 システム全体評価}

Table 7 にシステム全体の MAP 回収率集計表, Fig. 16 に 本システムによる MAP 回収シミュレーション例を示す。

Table 7 に表記した MAP 回収率等のデータは, 単位装 置を個別に稼動させたデータを重ね合わせて計算したも のである。4 種類の単位装置はいずれも単体としては MAP 回収率がほぼ 95\%以上であり, システム全体とし ては90.4\%であった。事前に設定した目標值の 90\%以上 を満足する結果を得ることが可能であった。

Fig. 16 は, 中規模下水処理場の污泥処理量: $100 \mathrm{t} /$ 日, 污 泥濃度 : $20 \mathrm{~g} / \mathrm{l}$, 污泥中 MAP 含有量 : $0.8 \mathrm{~g} / 1$ (本実験の A 処 理場污泥相当）を前提条件としたケーススタディーであ る。本 MAP 回収システムに供給される污泥に対して, 排 出される污泥は体積で 99.8\%, SS で 96.7\%, MAP 量で 9.6 \%であった。MAPを除く污泥成分はほぼ全量排出される ので，本システムを採用することにより後段の脱水処理 装置等は特に設計変更等を行う必要は無いと思われる。

\subsection{4 コスト評価}

Table 8 に本システムにより污泥から MAP を回収した

Table 7 MAP recovery in different tests

\begin{tabular}{llcc}
\hline \multirow{2}{*}{ Equipment } & Operating conditions & \multicolumn{2}{c}{ MAP recovery (\%) } \\
\cline { 3 - 4 } Vibrating screen & $\begin{array}{l}\phi 600 \mathrm{~mm} \\
\text { Openings: } 1.18 \mathrm{~mm} \\
\phi \mathrm{VF}: 35 \mathrm{~mm}\end{array}$ & 99.3 & 99.3 \\
\multirow{2}{*}{ inch hydrocyclone } & & 94.8 & 94.1 \\
\multirow{2}{*}{2 inch hydrocyclone } & $\begin{array}{l}\phi \mathrm{VF}: 14 \mathrm{~mm} \\
\phi S C: 6.4 \mathrm{~mm}\end{array}$ & 99.1 & 93.3 \\
MGS & $\begin{array}{l}\text { Gradient: } 4^{\circ} \\
\text { Rotating speed: } 318 \mathrm{rpm}\end{array}$ & 96.9 & 90.4 \\
\hline
\end{tabular}


Table 8 Cost comparison of two systems for the recovery of phosphorus

\begin{tabular}{lcc}
\hline \multirow{2}{*}{ Parameters } & \multicolumn{2}{c}{ Process } \\
\cline { 2 - 3 } & $\begin{array}{l}\text { MAP recovery from sludge } \\
\text { (system referred in Fig. 16) }\end{array}$ & $\begin{array}{c}\text { MAP crystallization } \\
\text { (existing process (2) in Table1) }\end{array}$ \\
\hline MAP recovery volume (kg/m -feed) & 0.7 & 1.4 \\
Power cost (Yen/kg-recovered MAP) & 22.3 & 20.3 \\
Chemical cost (Yen/kg-recovered MAP) & - & 81.0 \\
Total cost (Yen/kg-recovered MAP) & 22.3 & 101.3 \\
\hline
\end{tabular}

Object substance: Anaerobic digestive sludge $\left(\mathrm{PO}_{4}-\mathrm{P}: 300 \mathrm{mg} / \mathrm{l}\right.$, MAP content: $\left.0.8 \mathrm{~g} / \mathrm{l}\right)$

Feed rate: $200 \mathrm{~m}^{3} / \mathrm{D}$

MAP recovery rate in MAP crystallization: $75 \%$

Unit cost of electric power: $13 \mathrm{Yen} / \mathrm{kWh}$

Unit cost of $\mathrm{MgCl}_{2}: 539 \mathrm{Yen} / \mathrm{kg}-\mathrm{Mg}$

Unit cost of $\mathrm{NaOH}: 27 \mathrm{Yen} / \mathrm{kg}(48 \%-\mathrm{NaOH})$

場合と Table 1 に打いて紹介した(2)返流水 MAP 法 (MAP crystallization in returned water) とのコスト比較を示す。

Table 8 で比較対象として採用した(2)返流水 MAP 法は Table 1 の中で唯一複数の下水処理場（約 5 ヶ所）に沶い て採用実績のある方式である。コスト算出は, 本 MAP 回収システム, 及び(2)返流水 MAP 法の処理フローから 必要機器を推定し，処理規模を実装置レベルの日量 200 $\mathrm{t} /$ 日とし, 污泥中 MAP 量は A 処理場相当の $0.8 \mathrm{~g} / 1$ とし て, 移送ポンプや攪拌機等の付帯装置を全て含む設備と して計算した。な报，このコストシミュレーションは泒 泥性状や薬品単価等が変化すれば大きく変化する可能性 がある。

Table 8 の結果より, 本システムの回収 MAP $1 \mathrm{~kg}$ あた りの回収コストは(2)返流水 MAP 回収方式の 101.3 円 $/ \mathrm{kg}-$ 回収 MAP よりも大幅に小さい 22.3 円 $/ \mathrm{kg}$ - 回収 MAP で あり, 約 1/5 である。(2)返流水 MAP方式の主なコストは 薬品コストであり, 薬品を使用しない本システムはコス ト的に非常に有利であると判断できる。

\section{5. 結言}

本研究では下水污泥からのリン回収技術として, 実用 化を阻む最大の障壁である「処理コスト」に着目して実 用的技術の開発に取り組んできた。その結果として得ら れた知見を以下に列挙する。

1. 従来法としてのリン回収技術の中で自立採算性のある 実用的な方式はほとんど存在しないと考えられる。

2. 嫌気性消化污泥中には消化タンクの中で自然発生した 平均粒径約 $450 \mu \mathrm{m}$, 密度約 $1.7 \mathrm{~g} / \mathrm{cm}^{3}$ の MAP 粒子が, 約 $0.8 \mathrm{~g} / 1$ 存在することが明らかとなった。

3. 消化活泥中の MAP 粒子は 5 倍希釈沈降分離処理によ り污泥から容易に分離することが可能であり, この 5 倍希釈沈降分離法を採用寸ることにより MAP 分離装
置の簡易迅速評価を行らことが可能であることが分 かった。

3. パイロットスケールでの MAP 分離実験から,「振動ふ るい+4 インチ液体サイクロン +2 インチ液体サイクロ ン $+\mathrm{MGS} 」$ の処理フローにより污泥中の MAP の 90\% 以上を回収することが可能であることが分かった。ま た，回収産物の MAP 純度は最大で $88.2 \%$ であった。

4. 消化污泥 MAP回収システムによるMAP回収コストは 既存の返流水 MAP 回収法と比較して大幅に小さくな る可能性があることが分かった。

さらに, 著者らは今回の MAP 回収システムで得られ た産物を磁力選別することにより, MAP 純度を約 5〜10 \%高めることができることを明らかにしている7)。得ら れた MAP 産物は, 肥料取締法に基づく重金属などの規 制值をクリアして扣り, 遅効性の肥料として十分使用可 能であると考えられる。これらの結果を基に現在, 久留 米市の下水処理場に拉いて実証実験を行って扣り良好な 実験結果を得ている。

\section{References}

1) S. Ishida, K. Hanaki, T. Aramaki: The $38^{\text {th }}$ Mizu-Kankyo Gakkai Kouen-syu, p. 419 (2004)

2) T. Hagino, K. Sawai, T. Hirajima: The 41th Gesuido Kenkyu Happyou-kai Kouen-syu, pp. 462-464 (2004)

3) T. Hagino: Bunri-Gijutsu The $34^{\text {th }}$ volume 6 , pp. 379-383 (2004)

4) K. Moriyama: Journal of Japan Society on Water Environment, 27, 10, pp. 636-639 (2004)

5) K. Shimamura, T. Tanaka, H. Ishikawa: Gesuido-kyokaishi, 41, 502, pp. 115-125 (2004)

6) T. Hirajima, Y. Kubo, K. Suzuki: J.MMIJ (Shigen-toSozai) (Article in Press)

7) T. Hirajima, M. Kose, K. Sasaki, T. Hagino: Proc. MMIJ Annual Meeting Vol. II, pp. 175-176 (2005) 